\title{
The response of the equatorial tropospheric ozone to the Madden-Julian Oscillation in TES satellite observations and CAM-chem model simulation
}

\author{
W. Sun ${ }^{1}$, P. Hess ${ }^{2}$, and B. Tian ${ }^{3}$ \\ ${ }^{1}$ Department of Earth and Atmospheric Sciences, Cornell University, Ithaca NY, USA \\ ${ }^{2}$ Department of Biological and Environmental Engineering, Cornell University, Ithaca NY, USA \\ ${ }^{3}$ Jet Propulsion Laboratory, California Institute of Technology, Pasadena CA, USA \\ Correspondence to: W. Sun (ws299@cornell.edu)
}

Received: 15 April 2014 - Published in Atmos. Chem. Phys. Discuss.: 19 June 2014

Revised: 22 September 2014 - Accepted: 25 September 2014 - Published: 11 November 2014

\begin{abstract}
The Madden-Julian Oscillation (MJO) is the dominant form of the atmospheric intra-seasonal oscillation, manifested by slow eastward movement (about $5 \mathrm{~m} \mathrm{~s}^{-1}$ ) of tropical deep convection. This study investigates the MJO's impact on equatorial tropospheric ozone $\left(10^{\circ} \mathrm{N}-10^{\circ} \mathrm{S}\right)$ in satellite observations and chemical transport model (CTM) simulations. For the satellite observations, we analyze the Tropospheric Emission Spectrometer (TES) level-2 ozone profile data for the period of January 2004 to June 2009. For the CTM simulations, we run the Community Atmosphere Model with chemistry (CAM-chem) driven by the Goddard Earth Observing System Model, Version 5 (GEOS5)-analyzed meteorological fields for the same data period as the TES measurements. Our analysis indicates that the behavior of the total tropospheric column (TTC) ozone at the intra-seasonal timescale is different from that of the total column ozone, with the signal in the equatorial region comparable with that in the subtropics. The model-simulated and satellite-measured ozone anomalies agree in their general pattern and amplitude when examined in the vertical cross section (the average spatial correlation coefficient among the eight phases is 0.63 ), with an eastward propagation signature at a similar phase speed as the convective anomalies $\left(5 \mathrm{~m} \mathrm{~s}^{-1}\right)$. The model ozone anomalies on the intra-seasonal timescale are about 5 times larger when lightning emissions of $\mathrm{NO}_{\mathrm{x}}$ are included in the simulation than when they are not. Nevertheless, large-scale advection is the primary driving force for the ozone anomalies associated with the MJO. The variability related to the MJO for ozone reaches up to $47 \%$ of the total variability (ranging from daily to interan-
\end{abstract}

nual), indicating that the MJO should be accounted for in simulating ozone perturbations in the tropics.

\section{Introduction}

Tropospheric ozone is key in governing the tropospheric oxidation capacity through its role in producing hydroxyl $(\mathrm{OH})$ radicals (Lelieveld and Dentener, 2000), the primary chemical sink for many chemical pollutants. Tropical ozone is of particular importance as tropical $\mathrm{OH}$ removes approximately $85 \%$ of the methane molecules emitted in the atmosphere (e.g., Logan et al., 1981). Tropospheric ozone is also important in regulating the radiative forcing of climate (Worden et al., 2008; Lacis et al., 1990), with research suggesting that the tropics may be of particular importance (Houghton et al., 2001). However, the tropical tropospheric ozone distribution and variability have not been well documented and characterized, especially on the intra-seasonal timescale (e.g., Thompson et al., 2003). This is true in the observations, as well as in model simulations, where the focus has been on the climatology or seasonal variation of the tropospheric total column ozone in the tropics. This study investigates the dominant form of the intra-seasonal oscillation, the Madden-Julian Oscillation's (MJO) (Madden and Julian, 1972) impact on equatorial tropospheric ozone $\left(10^{\circ} \mathrm{N}-10^{\circ} \mathrm{S}\right)$ in satellite observations and in chemical transport model (CTM) simulations. 

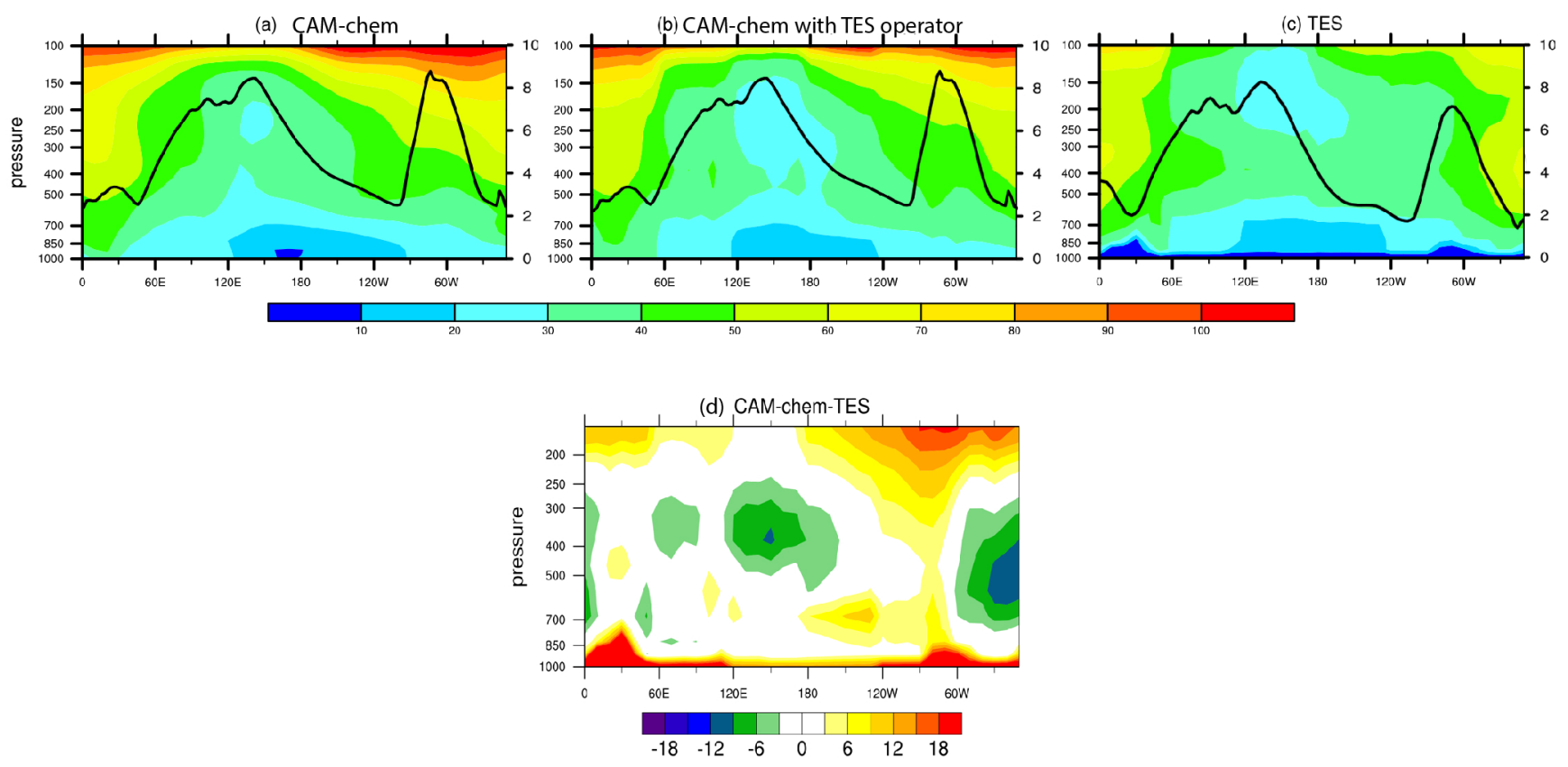

Figure 1. Climatology of tropospheric ozone (color, in ppb) during boreal winter (November-April) averaged between $10^{\circ} \mathrm{S}$ and $10^{\circ} \mathrm{N}$ for CAM-chem (a), CAM-chem with TES operator (b), TES (c) and difference between CAM-chem and TES (d) with precipitation (lines, right axis, in $\mathrm{mm} \mathrm{day}^{-1}$ ) from CAM-chem (a, b) and Tropical Rainfall Measuring Mission (TRMM) (c).

The MJO is characterized by slowly eastwardpropagating, large-scale oscillations in the tropical deep convection and baroclinic wind field, especially over the warmest tropical waters in the equatorial Indian and western Pacific oceans (e.g., Madden and Julian, 1971, 1972). In addition to its impacts on global weather and climate (Lau and Waliser, 2012), it has recently been recognized that the MJO can also affect atmospheric chemical composition, including components such as ozone, aerosols, carbon monoxide $(\mathrm{CO})$ and carbon dioxide $\left(\mathrm{CO}_{2}\right)$, as summarized in recent reviews (Tian and Waliser, 2011). For example, the MJO can impact the total column ozone (TCO). The associated TCO intra-seasonal anomalies are about \pm 10 Dobson Units (DU) and comparable to the TCO variability on annual and interannual timescales associated with $\mathrm{El}$ Niño-Southern Oscillation (ENSO), the quasi-biennial oscillation (QBO) and the solar cycle (Tian et al., 2007). The MJO impacts the TCO mainly through its impact on the vertical movement of tropopause. Partial ozone intra-seasonal anomalies maximize approximately in the lower stratosphere between 30 and $200 \mathrm{hPa}$ and account for more than $50 \%$ of the TCO anomalies (Li et al., 2012). The TCO intra-seasonal anomalies are mainly over the Pacific and eastern hemisphere and extend from the subtropics to the northern extratropics and the Arctic (Tian et al., 2007; Li et al., 2013).

The MJO can also impact the tropospheric ozone, especially near the Equator (e.g., Ziemke and Chandra, 2003; Ziemke et al., 2007; Cooper et al., 2013). It was found that the equatorial tropospheric column ozone as well as equatorial upper tropospheric ozone decreases during the enhanced phase of MJO events indicating that the MJO can directly impact the equatorial tropospheric column ozone and upper tropospheric ozone. These previous studies have shed light into the MJO's impacts on the tropospheric ozone, but large uncertainties may exist in their calculation of the tropospheric column ozone as it was calculated as a small residual of two large quantities, i.e., Total Ozone Mapping Spectrometer (TOMS) or Aura Ozone Monitoring Instrument (OMI) tropospheric column ozone (TCO) and Upper Atmosphere Research Satellite (UARS) or Aura Microwave Limb Sounder (MLS) stratospheric column ozone. Thus, satellite ozone data with vertical resolution in the troposphere will better define the impact of the MJO on tropospheric ozone.

In addition, model simulations also provide an essential tool in understanding how the MJO influences tropospheric ozone. During the MJO, large-scale overturning zonal circulations extend vertically through the troposphere and connect the regions of enhanced and suppressed convection (Zhang, 2005). This large-scale circulation and the deep convection associated with the MJO propagate together, making it difficult to separate their individual effects on the tropospheric ozone solely from the observations. However, model simulations can better isolate the different components of the MJO.

There are three ways that convection associated with the MJO can affect tropical tropospheric ozone. First, convection affects ozone by vertical mixing of ozone itself. Convection lifts lower tropospheric air to the upper troposphere 


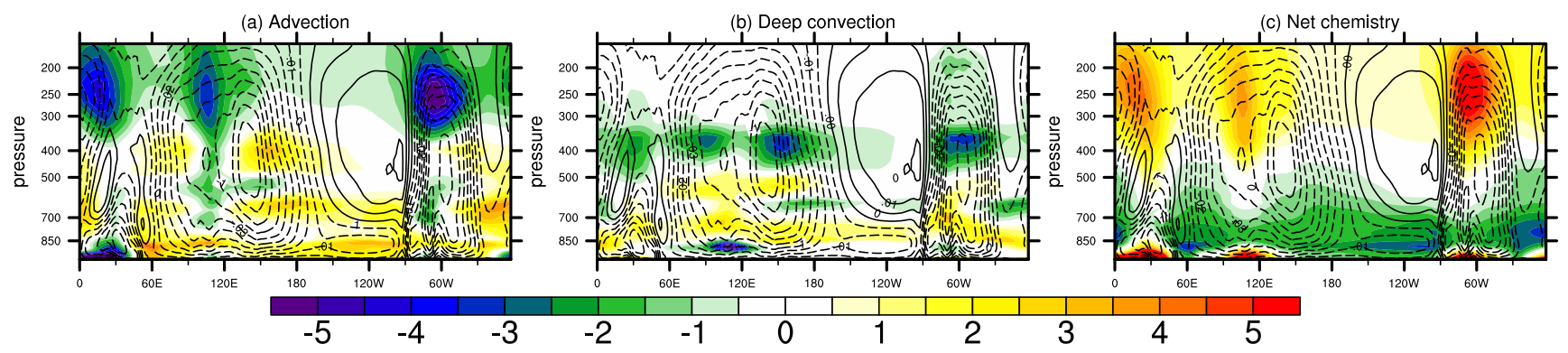

Figure 2. Vertical profile of the tropospheric climatology of the three major tendency terms (color, in $\mathrm{ppb}^{\mathrm{day}}{ }^{-1}$ ) for boreal winter (November-April) averaged between $10^{\circ} \mathrm{S}$ and $10^{\circ} \mathrm{N}$ : advection (a), deep convection (b) and net chemistry (c) with vertical velocity (dashed lines denote negative values/upward motions and solid lines represent the positive values/downward motions).

where the ozone lifetime is longer, while mass-balance subsidence mixes ozone-rich upper tropospheric air downwards to lower troposphere where the ozone lifetime is shorter (Lelieveld and Crutzen, 1994). This tends to decrease upper tropospheric ozone and the overall tropospheric column of ozone. Secondly, convection affects ozone by the vertical mixing of ozone precursors that influence tropospheric ozone chemical production and destruction. Where there are short-lived surface ozone precursor sources such as isoprene $\left(\mathrm{C}_{5} \mathrm{H}_{8}\right), \mathrm{NO}_{\mathrm{x}}\left(\mathrm{NO}+\mathrm{NO}_{2}\right)$, carbon monoxide $(\mathrm{CO})$ and hydrocarbons over polluted regions, convection significantly increases these precursor concentrations, and thus ozone, in the mid- and upper troposphere at the expense of concentrations in the lower troposphere. For example, Lawrence et al. (2003) found that lofting of surface $\mathrm{NO}_{\mathrm{x}}$ is a significant driver of increases in ozone production over much of the tropospheric column in a chemical transport model. Third, lightning in the tropics is a major $\mathrm{NO}_{\mathrm{x}}$ source (Sauvage et al., 2007; Ziemke et al., 2009) directly associated with convection, with most $\mathrm{NO}_{\mathrm{x}}$ added to the upper troposphere (Pickering et al., 1998). Labrador et al. (2005) found that lighting increased peak tropical ozone enhancements between 200 and $700 \mathrm{hPa}$ by $30 \%$, and peak $\mathrm{OH}$ enhancements by $100 \%$. Variations of lightning flash rate associated with the MJO over the Maritime Continent were found to be up to $50 \%$ of the annual mean flash rate (Virts et al., 2011, 2013). Despite its importance, the contribution of lightning-produced $\mathrm{NO}_{\mathrm{x}}$ is still very uncertain with global estimates ranging from 1 to $20 \mathrm{Tg}(\mathrm{N}) \mathrm{yr}^{-1}$ (Lawrence et al., 1995; Price et al., 1997).

Previous model studies show inconsistencies of convection's net effect on ozone due to different chemistry and convective schemes used in the models. Lelieveld and Crutzen (1994) used a model with no NMHC (non-methane hydrocarbon) chemistry and found convection caused a significant $20 \%$ decrease of total tropospheric ozone. Doherty et al. (2005) also found that convection reduced the global tropospheric ozone burden (by 13\%) using a more complex Lagrangian chemistry general circulation model (GCM; STOCHEM-HadAM3) with detailed NMHC chemistry. On the other hand, Lawrence et al. (2003), also using a com- plex CTM (MATCH-MPIC) with detailed NMHC chemistry, found vertical convective transport of ozone precursors outweighed the convective transport of ozone itself, resulting in a $12 \%$ increase in tropospheric ozone due to convection.

Thus, the dynamic (e.g., convection and large-scale circulation) versus chemical (ozone production/destruction due to ozone precursors such as isoprene, $\mathrm{NO}_{\mathrm{x}}$, hydrocarbons and lightning) contribution to the tropospheric ozone variations related to the MJO is still unclear. In this study, we examine the response of tropospheric ozone to the MJO in the equatorial region and the factors that drive the response using recent Tropospheric Emission Spectrometer (TES) ozone data and a chemical transport model (CAM-chem). Section 2 briefly describes the methodology. It includes a description of the chemical transport model, its analysis and the satellite data sets used for model evaluation. Section 3 evaluates the simulation of equatorial ozone climatology and the ozone MJO signal against TES ozone observations. Here, we also examine the sensitivity of the simulation with respect to lightning and analyze the importance of various processes in determining the ozone changes during the MJO. Section 4 analyzes the structure and processes determining the equatorial MJO of ozone in the model and observations. The conclusions are given in Sect. 5.

\section{Data and method}

\subsection{Satellite measurements}

The Level-2 (L2) ozone profiles measured by Tropospheric Emission Spectrometer (TES) from 30 August 2004 to 4 June 2009 (Beer et al., 2001; Jourdain et al., 2007; Worden et al., 2007) are used in this study. The TES instrument was launched in 2004 on the NASA Aura satellite into a sun-synchronous near-polar orbit with equatorial crossing times of 01:43 and 13:43 local solar time. TES is an infrared Fourier transform spectrometer, covering the spectral range $650-3050 \mathrm{~cm}^{-1}(3.3-15.4 \mathrm{~mm})$ (Beer, 2006). TES nadir observation have $0.1 \mathrm{~cm}^{-1}$ spectral resolution and a horizontal footprint of $5.3 \mathrm{~km} \times 8.5 \mathrm{~km}$. $\mathrm{O}_{3}$ profiles are retrieved from 

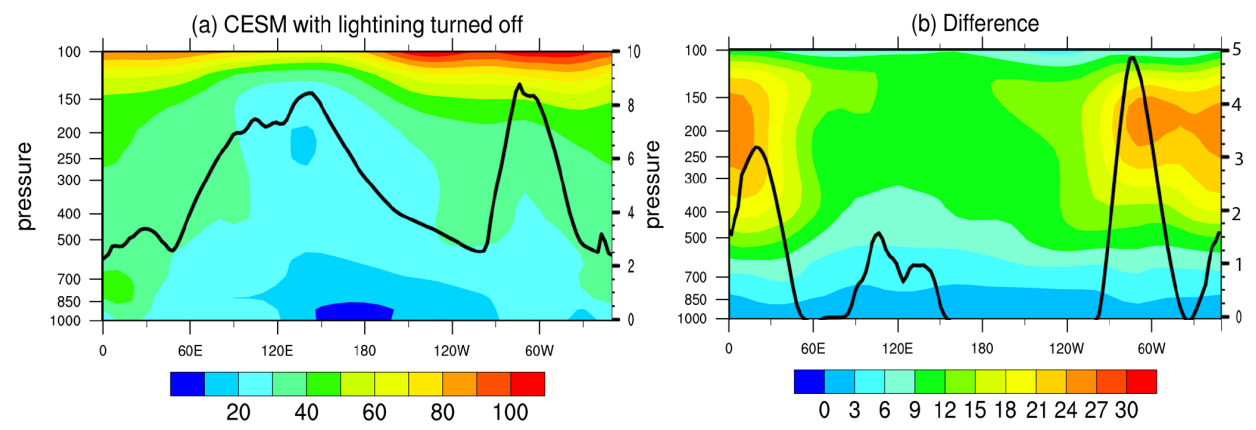

Figure 3. Tropospheric ozone climatology for boreal winter (November-April) averaged between $10^{\circ} \mathrm{S}$ and $10^{\circ} \mathrm{N}$ for (a) a run with $\mathrm{CAM}$ chem lightning turned off (color, in ppb) with precipitation (line, in $\mathrm{mm} \mathrm{day}^{-1}$ ) and (b) the difference between the control run and the run with lightning turned off (color, in ppb) with the lightning $\mathrm{NO}_{\mathrm{x}}$ source (line, in $1 \mathrm{e}^{-3} \mathrm{Tg} \mathrm{N} \mathrm{yr}^{-1}$ ).

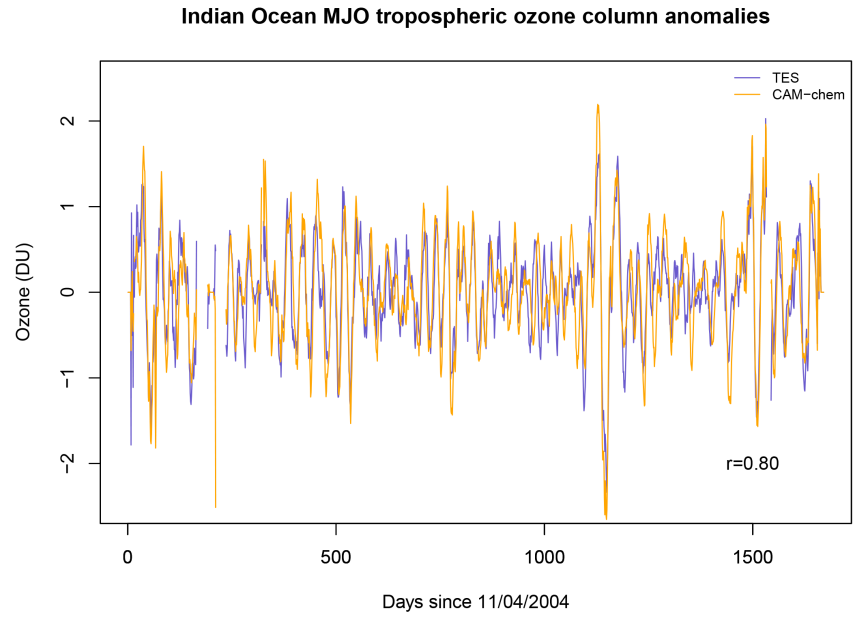

Figure 4. Time series of the 30-60-day bandpass filtered deseasonalized tropospheric ozone column anomalies (in DU) from TES and CAM-chem, averaged over the Indian Ocean $\left(45-100^{\circ} \mathrm{E}, 10^{\circ} \mathrm{S}-\right.$ $\left.10^{\circ} \mathrm{N}\right)$.

the infrared channels covering the $\mathrm{O}_{3} \nu_{3}$ band $\left(1050 \mathrm{~cm}^{-1}\right.$ or $9.6 \mathrm{~mm}$ ) using a nonlinear optimal estimation algorithm (Rodgers , 2000; Worden et al., 2004; Bowman et al., 2006) on 67 pressure levels between the surface and $5 \mathrm{hPa}$, with a vertical spacing of $0.7 \mathrm{~km}$ below $10 \mathrm{hPa}$. These infrared channels are most sensitive to $\mathrm{O}_{3}$ at levels between 900 and $30 \mathrm{hPa}$ with a vertical resolution of $6 \mathrm{~km}$ for clear sky scenes. The ozone profile estimates from TES have been compared with aircraft, in situ and model studies. TES ozone is biased high, particularly in the upper troposphere, by 3$10 \mathrm{ppb}$, compared to sonde (Nassar et al., 2008; Osterman et al., 2008; Worden et al., 2007) and lidar measurements (Richards et al., 2008). When and where there are optically thick clouds, the TES-retrieved $\mathrm{O}_{3}$ profiles below the optically thick clouds come mainly from the a priori $\mathrm{O}_{3}$ profile because the retrieved $\mathrm{O}_{3}$ information below the cloud tops can be very low (Kulawik et al., 2006; Eldering et al., 2008). The data used in this study is based on V004 TES data, which is available from the NASA Langley Atmospheric Data Center (http://eosweb.larc.nasa.gov/). To identify the convective features of the MJO, we use the V6 3B42 Tropical Rainfall Measuring Mission (TRMM) precipitation products (Huffman et al., 2007).

\subsection{Model}

The global Community Atmosphere Model with chemistry (CAM-chem), consisting of the atmosphere, land and chemical components of the Community Earth System model (CESM), is used to simulate the atmospheric chemistry and circulation associated with the MJO. Here, we use CAM4 from the version 1.0.4 of the CESM. Since we are most interested in the model simulation of the tropospheric ozone variation given realistic dynamical forcing of the MJO (convection, precipitation and large-scale circulation), the CAM-chem was driven by Goddard Earth Observing System Model, Version 5 (GEOS-5)-analyzed meteorological fields for the period January 2004 to June 2009 with the first 8 months used as spin up. The analysis starts from the date 31 August 2004.

We perform two simulations with CAM-chem: one control simulation and one simulation with no lightning emissions of $\mathrm{NO}_{\mathrm{x}}$. The latter simulation allows us to understand the role of lightning in the tropospheric ozone.

CAM-chem and its various components are described in detail in Lamarque et al. (2012). Deep convection uses the parameterization of the Zhang-McFarlane approach (Zhang and McFarlane, 1995) with some modifications, and shallow convection follows Hack et al. (2006). The planetary boundary layer is represented using the Holtslag and Boville (1993) parameterization. The model has a $1.9^{\circ} \times 2.5^{\circ}$ horizontal resolution and 56 vertical levels to $4 \mathrm{hPa}$, and the vertical coordinate is a hybrid sigma pressure (Lamarque et al., 2012). The chemistry used in CAM-chem is adapted from MOZART-4 (including 85 gas-phase species, 12 bulk aerosol compounds, 39 photolysis and 157 gas-phase reactions (Emmons et al., 2010), by adding chemical reactions for $\mathrm{C}_{2} \mathrm{H}_{2}, \mathrm{HCOOH}$, 

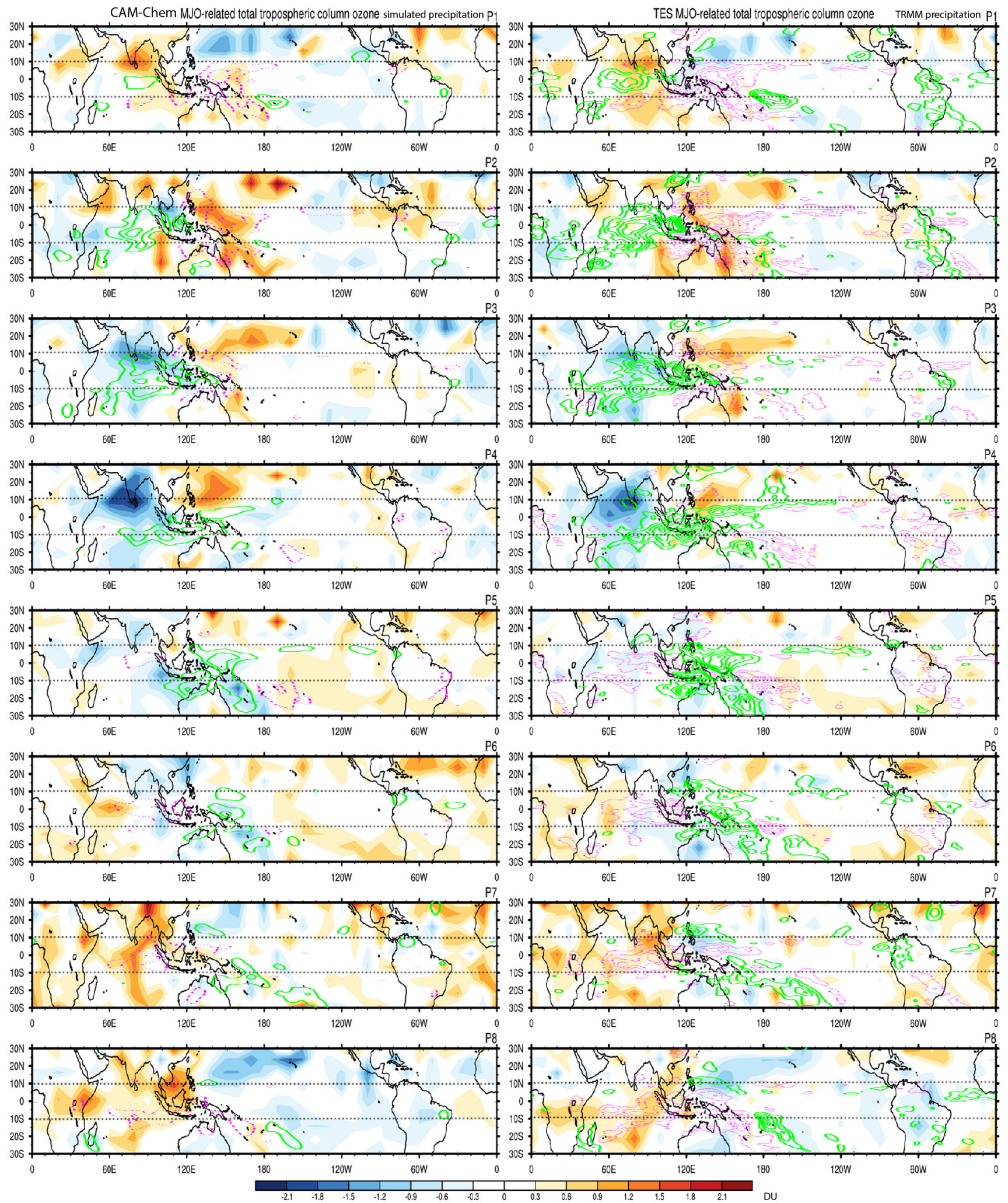

Figure 5. Left: composite life cycle (phase 1 to 8 ) of the MJO-related total tropospheric column ozone (color, in DU) for CAM-chem (with the TES operator applied) with precipitation (green lines as positive and purple lines as negative); right: composite life cycle of the MJOrelated TTC ozone for TES (color, in DU) with TRMM precipitation (green lines as positive and purple lines as negative) for $30^{\circ} \mathrm{S}$ to $30^{\circ} \mathrm{N}$. The precipitation is contoured from -3 to $3 \mathrm{~mm}_{\text {day }}{ }^{-1}$ with $0.5 \mathrm{~mm}_{\text {day }}{ }^{-1}$ intervals. 
$\mathrm{HCN}$ and $\mathrm{CH}_{3} \mathrm{CN}$ and minor changes to the isoprene oxidation scheme (Lamarque et al., 2012). Stratospheric chemistry is not explicitly represented, and ozone from the model top to $50 \mathrm{hPa}$ uses input monthly mean climatological ozone concentrations from 1950 to 2005 from Whole Atmosphere Community Climate Model (WACCM) simulations (Garcia et al., 2007). Between $50 \mathrm{hPa}$ and two model levels above the tropopause (approximately $150 \mathrm{hPa}$ ) ozone is relaxed to the WACCM distribution with a 10-day relaxation time.

The anthropogenic emissions for most species are from the POET (Precursors of Ozone and their Effects in the Troposphere) database for 2000 (Granier et al., 2005). Anthropogenic emissions for $\mathrm{SO}_{2}$ and $\mathrm{NH}_{3}$ are taken from the EDGAR-FT2000 and EDGAR-2 databases (http://www. mnp.nl/edgar/). Aircraft emissions of $\mathrm{NO}, \mathrm{CO}$ and $\mathrm{SO}_{2}$ from scheduled, charter, general aviation and military traffic for 1999 are included (Baughcum et al., 1996, 1998; Mortlock and Van Alstyne, 1998; Sutkus et al., 2001) and have global annual totals of $0.63 \mathrm{Tg} \mathrm{yr}^{-1}\left(1.35 \mathrm{Tg} \mathrm{N} \mathrm{yr}^{-1}\right)$ for $\mathrm{NO}$, $1.70 \mathrm{Tg} \mathrm{yr}^{-1}$ for $\mathrm{CO}$ and $0.16 \mathrm{Tg} \mathrm{yr}^{-1}$ for $\mathrm{SO}_{2}$ (Emmons et al., 2010). Monthly average biomass burning emissions for each year come from the Global Fire Emissions Database, version 2 (GFED-v2), which is currently available for 19972007 (van der Werf et al., 2006). Emissions for species not provided in GFED (e.g., individual volatile organic compounds as specified in MOZART-4, $\mathrm{SO}_{2}$, and $\mathrm{NH}_{3}$ ) are determined by scaling the GFED $\mathrm{CO}_{2}$ emissions by the emission factors of Andreae and Merlet (2001) and updates to it (Granier et al., 2005), using the vegetation classification provided with GFED. The emissions of NO from lightning are based on the Price and Rind parameterization (Price and Rind, 1992; Price et al., 1997), providing a global annual emission of 3-5 $\mathrm{Tg}(\mathrm{N}) \mathrm{yr}^{-1}$ (Lamarque et al., 2012). To fully exploit the advantage of using the earth system model, we use the land model to interactively calculate the emissions of biogenic hydrocarbons based on the Model of Emissions of Gases and Aerosols from Nature (MEGAN) algorithm (Guenther et al., 2006).

To compare the simulated ozone with TES observations, the TES operator is applied to the simulation data. After extracting co-located spatial and temporal points from the simulation, the ozone is interpolated vertically to match the observed pressure levels of the satellite data, then adjusted using the a priori profiles and the averaging kernel matrices (jointly referred to as observation operator) to account for limited vertical resolution of observations and the impact of clouds (Kulawik et al., 2006).

Within the model simulation, we separate the ozone tendency into various processes so as to understand how the ozone climatology is maintained and how the MJO changes the ozone distribution. In every grid box, the ozone change is attributed to the following tendency terms: advection (horizontal and vertical advection), deep convection, chemistry, shallow convection and vertical diffusion.

$$
\begin{aligned}
& \left(\frac{\partial \mathrm{O}_{3}}{\partial t}\right)=\left(\frac{\partial \mathrm{O}_{3}}{\partial t}\right)_{\text {advection }}+\left(\frac{\partial \mathrm{O}_{3}}{\partial t}\right)_{\text {deep convection }} \\
& +\left(\frac{\partial \mathrm{O}_{3}}{\partial t}\right)_{\text {chemistry }}+\left(\frac{\partial \mathrm{O}_{3}}{\partial t}\right)_{\text {shallow convection }} \\
& +\left(\frac{\partial \mathrm{O}_{3}}{\partial t}\right)_{\text {vertical diffusion }}
\end{aligned}
$$

Results (not shown) indicate that shallow convection and vertical diffusion are much smaller than the other three terms and are not further analyzed. The advective algorithm (the flux form of the semi-Lagrangian scheme) does not readily allow the differentiation of advection into vertical and horizontal components.

\subsection{Data analysis}

The analysis method is similar to that used in our previous studies (e.g., Tian et al., 2010, 2011; Li et al., 2012, 2013). To isolate the MJO signal in the satellite-measured and model-simulated data, the average annual cycle of each field is first calculated and smoothed with a 30-day running average; then, daily anomaly signals are obtained by subtracting the smoothed annual cycle from daily data. Finally, the MJO signal is obtained by applying a 30-60-day bandpass filter to the daily anomalies. The daily MJO anomalies are sorted into eight MJO phases according to the allseason realtime multivariate MJO (RMM) index, which is constructed using the combined empirical orthogonal function (EOF) of the equatorial mean $\left(15^{\circ} \mathrm{S}-15^{\circ} \mathrm{N}\right)$ outgoing longwave radiation and 200 and $850 \mathrm{hPa}$ zonal winds, and the leading two EOFs explain $25 \%$ of the variance of these fields (Wheeler and Hendon, 2004). This daily index characterizes the state of the MJO in terms of its amplitude and phase, where the latter divides the MJO cycle (typically about 40 55 days) into eight phases, each roughly lasting about 6 days. Phase 1 represents developing positive rainfall anomalies in the western Indian Ocean, with the sequential progression to Phase 8 corresponding to the eastward propagation of positive rainfall anomalies across the eastern Indian Ocean, Maritime Continent, western Pacific and onto the central/eastern Pacific (Hendon and Salby, 1994). In this study, composite MJO cycles of the quantities of interest, such as rainfall and $\mathrm{O}_{3}$, are produced by separately averaging together all daily anomaly values of the given quantity for each phase of the MJO, considering only strong amplitude events where $\mathrm{RMM}_{1}{ }^{2}+\mathrm{RMM}_{2}{ }^{2}>1$. We restrict our analysis to the Northern Hemisphere (boreal) winter months (November to April) from 2004 to 2009 because the MJO signal is stronger when the Indo-Pacific warm pool is centered near the equator. When performing the model and TES comparison, we binned the data into $20^{\circ}$ latitude $\left(10^{\circ} \mathrm{N}-10^{\circ} \mathrm{S}\right) \times 10^{\circ}$ longitude bins to have sufficient daily data. The number of TES observations per latitude/longitude bin ranges from zero to eight per 

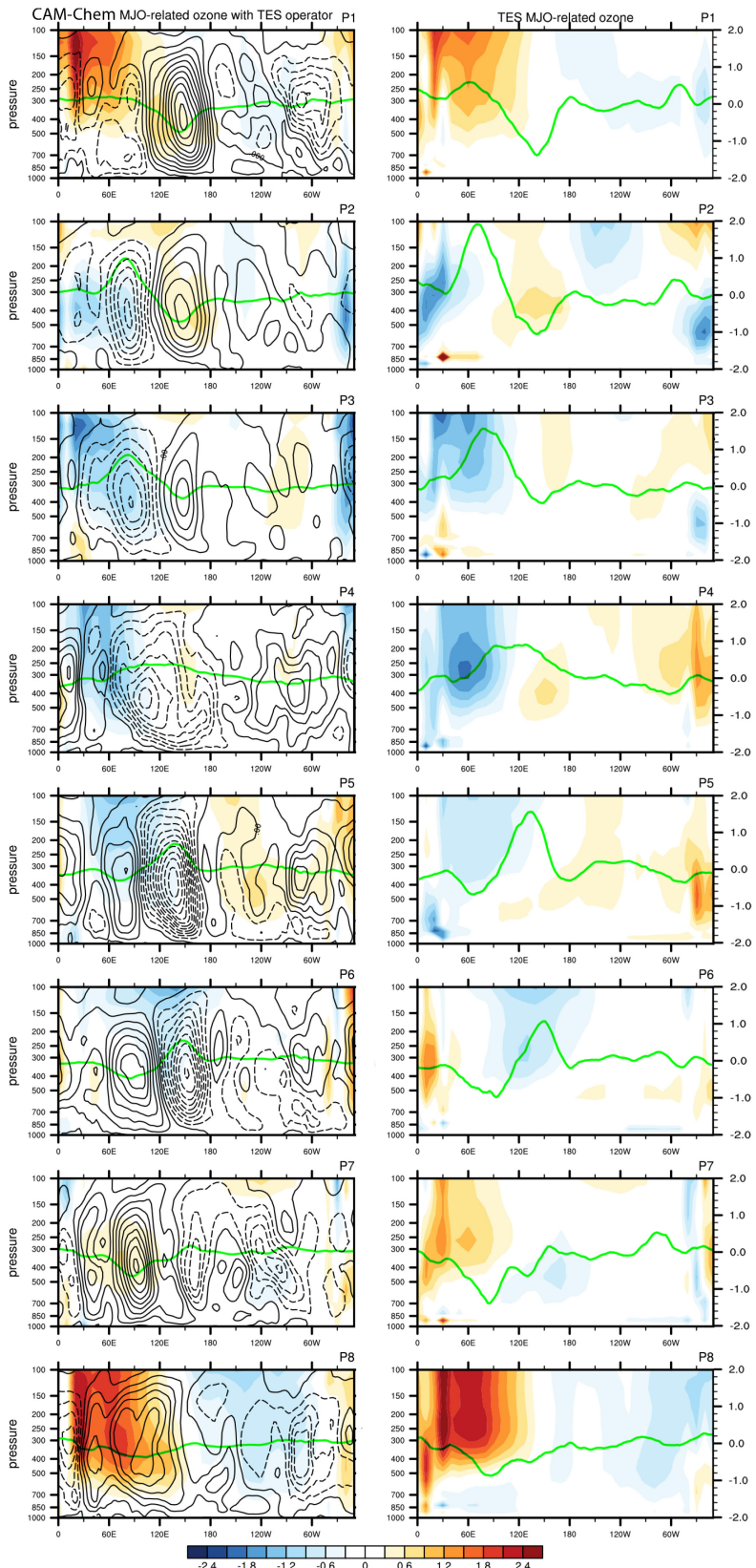

Figure 6. Left: MJO-related ozone anomalies (color, in ppb) for CAM-chem (with the TES operator applied) with GEOS-5 vertical velocity (dashed black lines as negative and solid black lines as positive) and precipitation (green lines, in mm day ${ }^{-1}$ ); right: MJO-related ozone anomalies (color, in ppb) for TES with TRMM precipitation (green lines, in mm day ${ }^{-1}$ ).

day and the average number of observations for all the bins of the $10^{\circ} \mathrm{S}$ to $10^{\circ} \mathrm{N}$ area is approximately one to two per day.

\section{Climatological ozone distribution}

CAM-chem has been extensively evaluated (Lamarque et al., 2012). A comparison of the model against tropical ozonesonde measurements suggests a positive surface bias of approximately $20-40 \%$ for all seasons, a good simulation throughout the mid-troposphere and a positive upper tropospheric bias above $400 \mathrm{hPa}$ of approximately $40 \%$ from December through May (Lamarque et al., 2012). Here, we analyze and evaluate the CAM-chem climatology in the equatorial region $\left(10^{\circ} \mathrm{N}-10^{\circ} \mathrm{S}\right)$ for the months of November-April from 2004 to 2009. 


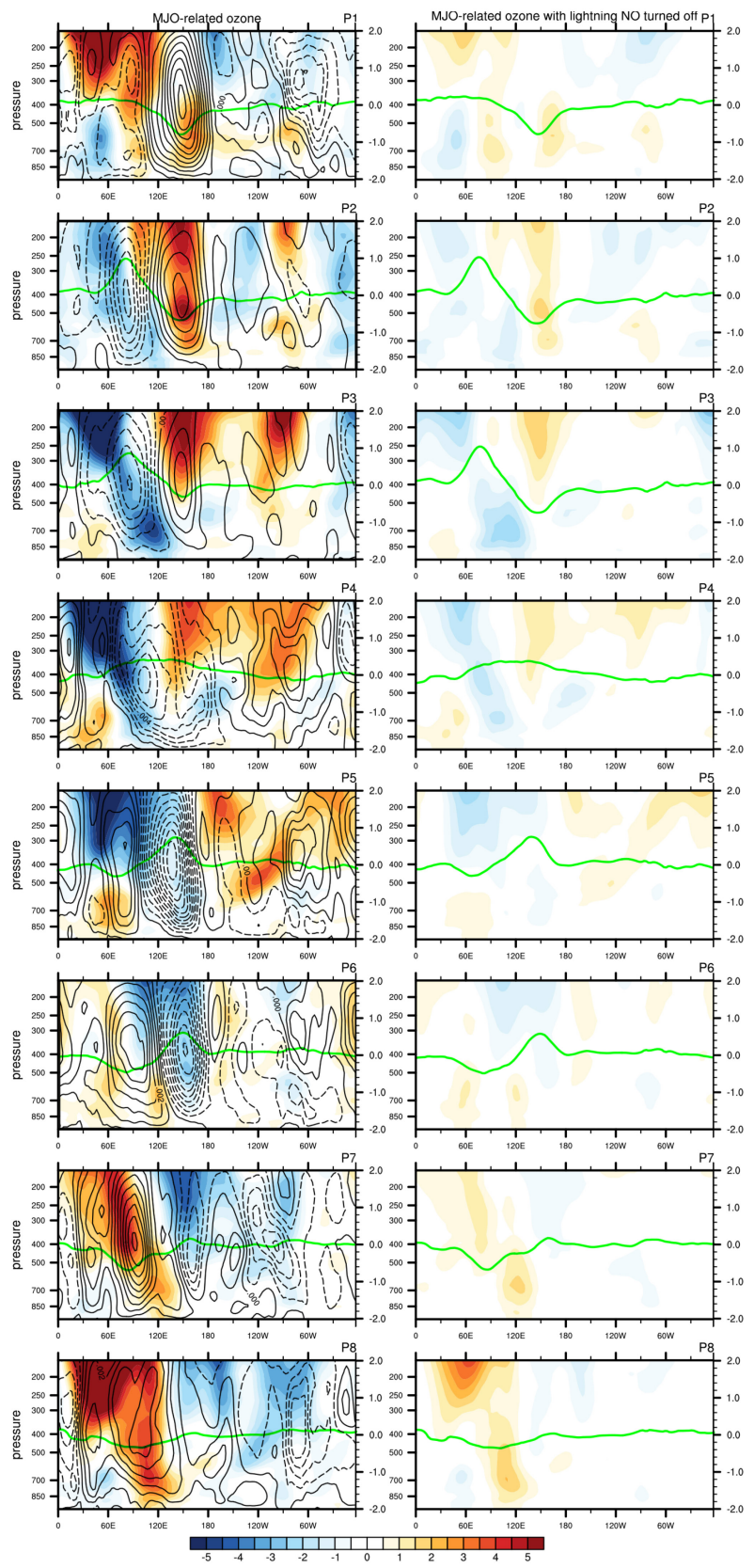

Figure 7. Left: MJO-related ozone anomalies (color, in ppb) with GEOS-5 vertical velocity (dashed black lines as negative and solid black lines as positive) and precipitation (green lines, in $\mathrm{mm} \mathrm{day}^{-1}$ ) for the control run; right: MJO-related ozone anomalies (color, in ppb) and precipitation (green lines, in $\mathrm{mm} \mathrm{day}^{-1}$ ) for the run with lightning NO turned off.

\subsection{Climatology of equatorial tropospheric ozone}

CAM-chem-simulated and TRMM-measured tropical precipitation show good agreement both in their spatial distribution and magnitude. Climatological precipitation local maxima are found near $100^{\circ} \mathrm{E}, 150^{\circ} \mathrm{E}$ and $60^{\circ} \mathrm{W}$ both in the model simulation and satellite observations (Fig. 1), indicating strong convection at these longitudes. A local maximum of precipitation at $30^{\circ} \mathrm{E}$ was found only in the model simulation but not in the TRMM data. The CAM-chemsimulated ozone distribution with the TES averaging kernel applied and the TES ozone distribution are highly correlated (spatial correlation coefficient is 0.84 from $200 \mathrm{hPa}$ to surface; Fig. 1). From 30 to $80^{\circ} \mathrm{E}$, high ozone concentrations are evident throughout most of the depth of the troposphere in both model simulation and satellite measurements. Near $100^{\circ}$ and $150^{\circ} \mathrm{E}$, low ozone concentrations are evident throughout the depth of the troposphere in both the model 

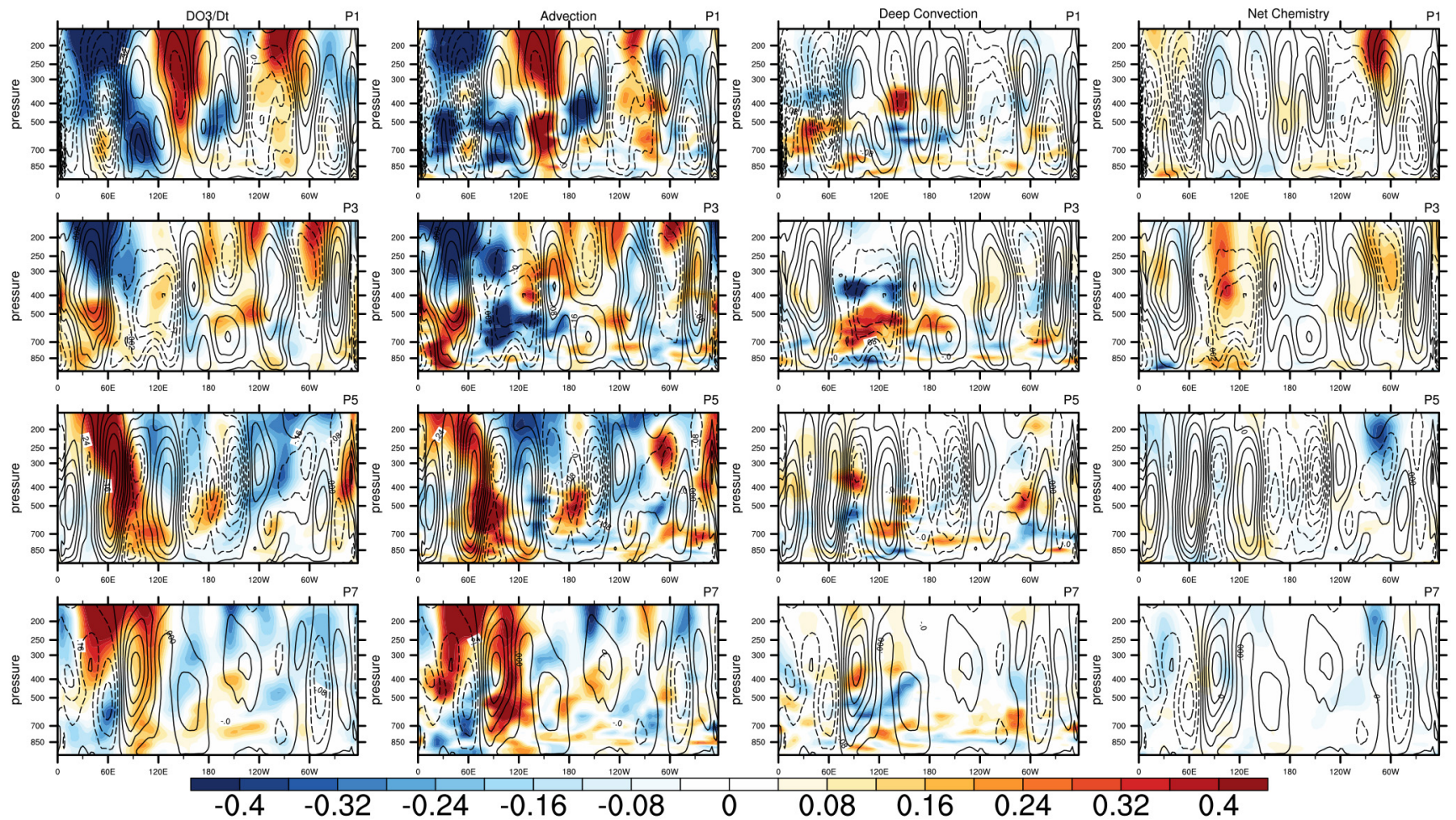

Figure 8. MJO-related tendency $\left(\left(\frac{\partial \mathrm{O}_{3}}{\partial t}\right),\left(\frac{\partial \mathrm{O}_{3}}{\partial t}\right)_{\text {advection }},\left(\frac{\partial \mathrm{O}_{3}}{\partial t}\right)_{\text {deep convection }},\left(\frac{\partial \mathrm{O}_{3}}{\partial t}\right)_{\text {chemistry }}\right.$, color, in ppb day $\left.{ }^{-1}\right)$ with vertical velocities (dashed lines as negative and solid lines as positive).

simulation and satellite measurements. They are associated with a precipitation maximum and have been attributed to enhanced convection transporting low ozone concentrations from the oceanic boundary layer to the upper troposphere (Lelieveld et al., 2001). The precipitation maximum near $60^{\circ} \mathrm{W}$ in equatorial South America, however, is not associated with low upper tropospheric ozone concentrations in either the model simulation or the satellite measurements due probably to the high surface ozone concentration over land (see Sect. 3.1.2). This may also be true for the local precipitation maximum and high upper tropospheric ozone concentrations near $30^{\circ} \mathrm{E}$ over equatorial Africa. However, there are some detailed differences between the CAM-chem model simulation and the TES satellite observations. For example, CAM-chem has a positive bias of ozone $(\sim 10 \mathrm{ppb})$ compared with TES (Fig. 1d) over the upper troposphere with the largest bias located near $90-60^{\circ} \mathrm{W}$. In the middle troposphere over the western Pacific (near $150^{\circ} \mathrm{E}$ ) and near the date line, the model-simulated ozone is generally less than the satellite-measured ozone ( $\sim 10 \mathrm{ppb})$. In the boundary layer, the CAM-chem is positively biased compared with TES. The TES boundary layer ozone distribution is determined primarily by the a priori distribution and so may not reflect the actual ozone distribution there. The TES operator does not dramatically change the simulated ozone distribution (compare Figs. 1b and 1a), although the result of ap- plying the TES operator is an increase in the boundary layer ozone and a reduction in the upper tropospheric ozone (near the date line). The CAM-chem-simulated ozone concentration with TES operator applied (Fig. 1b) is consistent with simulations using GEOS-Chem (Bowman et al., 2009).

\subsection{The climatological tendency terms}

In the climatological sense, the net ozone tendency (Eq. 1) is close to zero. In the upper troposphere, both advection and deep convection decrease ozone above $400-500 \mathrm{hPa}$ as they transport depleted ozone upwards (Fig. 2). The pronounced convective ozone reductions generally occur in a sharply defined layer from 300 to $500 \mathrm{hPa}$ (approximately $7-10 \mathrm{~km})$, which is lower than altitudes of $12-14 \mathrm{~km}(150$ $200 \mathrm{hPa}$ ) of strong tropical convection outflow suggested by Folkins and Martin (2005) and Randel and Jensen (2013). However, note that near $60^{\circ} \mathrm{W}$ a convective signal is simulated at higher altitudes, near $200 \mathrm{hPa}$. The minimum deep convection tendencies near $30^{\circ} \mathrm{E}, 90^{\circ} \mathrm{E}, 160^{\circ} \mathrm{E}$ and $60^{\circ} \mathrm{W}$ near $400 \mathrm{hPa}$ co-locate with the precipitation local maxima (Fig. 1). Above $300 \mathrm{hPa}$, large-scale advection reduces ozone concentrations everywhere, with the largest reductions above regions of strong convective ozone reductions (with the exception of $150^{\circ} \mathrm{E}$ ). The large reductions of ozone can be attributed to large-scale ascent above the level of maximum 
convection (Randel and Jensen, 2013). Chemical ozone production is generally positive above $400 \mathrm{hPa}$, with the strong positive ozone production coincident with regions of large advective ozone decreases, consistent with the results from Folkins et al. (2002, Fig. 14). Note that the tendency of chemistry and advection are opposing at the altitudes of $7-12 \mathrm{~km}$ (400 to $200 \mathrm{hPa}$ ).

In the lower troposphere, transport generally increases the ozone concentration as ozone-rich air subsides in the vicinity of deep moist convection (Lelieveld and Crutzen, 1994; Doherty et al., 2005). Positive convective transport is particularly noticeable below regions with pronounced negative convective transport at $400 \mathrm{hPa}$. An exception to the lowerlevel convective increase of ozone occurs near $90-120^{\circ} \mathrm{E}$, a region where chemical ozone production is pronounced and convection decreases boundary layer ozone. Low-level ozone enhancements are also evident near $90^{\circ} \mathrm{W}$, associated with the subsiding motion associated with the Walker circulation. Net chemical destruction generally balances the positive transport tendencies below approximately $600 \mathrm{hPa}$. In the boundary layer near $30^{\circ} \mathrm{E}, 120^{\circ} \mathrm{E}$ and $60^{\circ} \mathrm{W}$, the net chemical production is positive, probably resulting from the strong surface emissions in these regions.

\subsection{The climatological role of lightning}

Lightning $\mathrm{NO}_{\mathrm{x}}$ emission is an important component of the tropical ozone budget. The largest model-simulated lightning $\mathrm{NO}_{\mathrm{x}}$ sources occur near $30^{\circ} \mathrm{E}, 100^{\circ} \mathrm{E}, 150^{\circ} \mathrm{E}$ and $60^{\circ} \mathrm{W}$ (Fig. 3b). These lightning $\mathrm{NO}_{\mathrm{x}}$ source local maxima all correspond to precipitation local maxima. These regions are also associated with the strong positive net chemistry tendencies in the upper troposphere (Fig. 2). Parameterized lightning $\mathrm{NO}_{\mathrm{x}}$ emissions are larger over land $\left(30^{\circ} \mathrm{E}-\right.$ Africa, $60^{\circ} \mathrm{W}$ - South America) and considerably reduced over the ocean $\left(150^{\circ} \mathrm{E}\right.$ - western Pacific) and Maritime Continent $\left(100^{\circ} \mathrm{E}\right)$, consistent with observations (Price and Rind, 1992).

The ozone distribution in the control run (Fig. 1a) and the simulation where the lightning $\mathrm{NO}_{\mathrm{x}}$ emissions are turned off (Fig. 3a) are qualitatively similar where both show a "waveone" pattern with an ozone maximum over the tropical Atlantic and a minimum over the tropical Pacific; however, the simulation without lightning generally reduces ozone everywhere and in particular reduces the longitudinal and vertical tropical ozone gradients (Fig. 3b). The difference between the control run and the simulation with no lightning reaches up to $30 \mathrm{ppb}$ in the upper troposphere near $60^{\circ} \mathrm{W}$ and $10^{\circ} \mathrm{E}$ (where the lightning NO source is maximal), consistent with the differences found by Sauvage et al. (2007, Fig. 6) but larger than the approximately $20 \mathrm{ppb}$ differences suggested in Martin et al. (2002, Fig. 15). The largest differences between the simulations with and without lightning do not occur where the peak lightning $\mathrm{NO}_{\mathrm{x}}$ emissions are located, indicating that the relationship between lighting $\mathrm{NO}_{\mathrm{x}}$ emissions and the ozone bias is not completely straightforward.
Table 1. Longitude-latitude $\left(30^{\circ} \mathrm{S}-30^{\circ} \mathrm{N}\right)$ spatial correlation coefficients between modeled and measured ozone and precipitation anomalies, correlated for each phase of the MJO between CAMchem and TES tropospheric ozone column (324 points) and CAMchem and TRMM precipitation (4608 points). All correlation coefficients pass the Student's $t$ test at $95 \%$ confidence level.

\begin{tabular}{lrr}
\hline Phase & Ozone & Precipitation \\
\hline 1 & 0.565 & 0.759 \\
2 & 0.676 & 0.775 \\
3 & 0.699 & 0.789 \\
4 & 0.725 & 0.765 \\
5 & 0.614 & 0.782 \\
6 & 0.632 & 0.763 \\
7 & 0.710 & 0.727 \\
8 & 0.641 & 0.740 \\
\hline
\end{tabular}

The large lightning $\mathrm{NO}_{\mathrm{x}}$ source from $80^{\circ} \mathrm{W}$ to $50^{\circ} \mathrm{E}$ can explain the relatively high ozone concentration over South America, the Atlantic Ocean and Africa. On the other hand, the relatively low lightning $\mathrm{NO}_{\mathrm{x}}$ emissions in the Pacific must be an important factor in maintaining the rather low upper tropospheric ozone concentrations there.

\section{Simulated and measured MJO signal}

In this section, we discuss the MJO signal in equatorial tropospheric ozone in satellite observations and CAM-chem simulations and analyze the budget terms responsible for the model-simulated MJO-related equatorial tropospheric ozone changes.

The region $\left(45-100^{\circ} \mathrm{E}, 10^{\circ} \mathrm{S}-10^{\circ} \mathrm{N}\right)$ over the Indian Ocean is chosen for examining the MJO-related tropospheric column ozone anomalies (deseasonalized 30-60-day bandpass filtered) time series from November 2004 to June 2009 (Fig. 4). The correlation of the CAM-chem-simulated and TES-observed tropospheric column ozone anomalies is 0.8 , which is significant at the Student's $t$ test $95 \%$ confidence level. The peak-to-peak variability reaches up to $4-5 \mathrm{DU}$, suggesting that $\mathrm{MJO}$ is an important process influencing the equatorial tropospheric ozone column.

\subsection{MJO signal in TTC ozone}

The patterns of simulated and measured total tropospheric column (TTC) ozone anomalies and precipitation anomalies for the eight phases of the MJO (Wheeler and Hendon, 2004) are in overall agreement (Fig. 5) both in the tropics and the subtropics (the average spatial correlation coefficient is 0.658 for ozone and 0.762 for precipitation, both statistically significant; see Table 1 for the model-measurement spatial correlation coefficient for each phase). The positive precipitation anomalies (green lines), indicating the convectionactive center, originate in the western Indian Ocean (phase 
Table 2. Longitude-altitude (surface to $100 \mathrm{hPa}$ ) spatial correlation coefficients between modeled and measured ozone anomalies and longitudinal correlation coefficients between modeled and measured precipitation anomalies, correlated for each phase of the MJO between CAM-chem and TES tropospheric ozone column (936 points) and CAM-chem and TRMM precipitation (144 points). Fields are averaged from $10^{\circ} \mathrm{S}$ to $10^{\circ} \mathrm{N}$. All correlation coefficients pass the Student's $t$ test at $95 \%$ confidence level.

\begin{tabular}{lrr}
\hline Phase & Ozone & Precipitation \\
\hline 1 & 0.779 & 0.940 \\
2 & 0.603 & 0.973 \\
3 & 0.616 & 0.975 \\
4 & 0.696 & 0.965 \\
5 & 0.676 & 0.979 \\
6 & 0.524 & 0.976 \\
7 & 0.400 & 0.957 \\
8 & 0.802 & 0.910 \\
\hline
\end{tabular}

1), move eastward to the eastern Indian Ocean (phase 2 and 3), Maritime Continent (phase 4 and 5), western Pacific (phase 6 and 7) and central/eastern Pacific Ocean (phase 8), consistent with the previous MJO studies (e.g., Hendon and Salby, 1994). While the magnitude of the model-simulated and satellite-measured ozone anomalies are in general agreement, the magnitude and the spatial scale of the precipitation anomalies in CAM-chem are smaller than that observed in TRMM. The magnitude of MJO-related TTC ozone anomalies in the equatorial region is comparable to that in the subtropics. On the other hand, Tian et al. (2007) showed that the satellite derived MJO-related TCO anomalies are larger in the subtropics than in the equatorial region. This suggests that the behavior of the TTC ozone on the intra-seasonal timescale is different from that of the TCO, especially in the equatorial region. In Fig. 6, the vertical ozone anomaly pattern between $10^{\circ} \mathrm{N}$ and $10^{\circ} \mathrm{S}$ is analyzed in detail.

\subsection{Vertical profiles of the MJO-related tropospheric ozone anomalies}

The phase of the precipitation anomalies in the model and measurements are in general agreement (Figs. 5, 6). Consistent with previous analyses (e.g., Zhang, 2005), the MJO convective signal is characterized by an eastward moving precipitation anomaly with greatest amplitude in the western Pacific. A slight positive precipitation anomaly is observed over the equatorial central Indian Ocean (near $60^{\circ} \mathrm{E}$ ) in phase 1 ; it then becomes amplified and moves slowly eastward across the Maritime Continent and western equatorial Pacific in phases 2-6. It finally disappears over the central equatorial Pacific in phases 7-8. Similarly, a slight negative precipitation anomaly is observed over the equatorial central Indian Ocean (near $60^{\circ} \mathrm{E}$ ) in phase 5 , it then becomes amplified and moves slowly eastward across the Maritime Con- tinent and western equatorial Pacific in phases 6-8-1-3. It finally disappears over the central equatorial Pacific in phase 4.

The vertical velocity anomaly fields derived from the GEOS-5 analyses (Fig. 6) are consistent with those derived from National Centers for Environmental Prediction (NCEP) reanalysis data as given in Zhang and Mu (2005). The precipitation anomalies are clearly associated with pronounced anomalies in the vertical velocity consistent with previous studies (e.g., Jee-Hoon et al., 2008). Phases 1 through 6 are characterized by a generally strengthening upward vertical velocity anomaly moving slowly eastward, coincident with the positive precipitation anomaly. Weakened upward vertical velocities are located over the eastern Pacific for phases 7 and 8. Similar to the negative precipitation anomaly, the downward anomaly in vertical velocity is identified over the central Indian Ocean in phase 5 and moves eastward from phase 6-3 before it finally weakens in phase 4 in the western hemisphere.

The MJO ozone anomalies in the upper level of the atmosphere (e.g., $200 \mathrm{hPa}$ ) (Fig. 6) are similar to the TTC ozone anomalies shown in Fig. 5 as the ozone change in the upper troposphere dominates that in the lower troposphere. The largest ozone anomalies occur in the Indian Ocean and western Pacific in association with the largest vertical velocity anomalies. The total and upper tropospheric ozone anomalies move eastward with the eastward propagation of the largescale MJO convective and dynamical anomalies.

Viewed in the vertical, the modeled and measured ozone anomalies generally agree in pattern and amplitude, with the average spatial correlation coefficient of 0.63 for the eight phases, which is significant at the $95 \%$ confidence level (Table 2 gives the correlation coefficients for each phase). In both the model simulation and satellite measurement, a pronounced positive $\mathrm{O}_{3}$ anomaly occurs in the Indian Ocean during phase 1 centered in the very upper troposphere over the region of the slightly positive rainfall anomaly and to the west of the negative rainfall anomaly. During phases 2-3, this positive $\mathrm{O}_{3}$ anomaly shifts eastward and weakens considerably. In both the model simulation and satellite measurement, the positive ozone anomaly in phase 1 over the Indian Ocean is replaced by a negative anomaly in phase 2 centered in the middle troposphere. During phases 2-6, this negative ozone anomaly shifts eastward and is coincident with or located slightly to the west of the positive rainfall anomaly. During phases $6-8$, the positive $\mathrm{O}_{3}$ anomaly rebuilds over western portion of the equatorial domain. The ozone signal in the eastern portion of the domain propagates very little but is generally out of phase with the signal in the western portion of the domain. Model-measurement ozone discrepancies exist in the sign near $30^{\circ} \mathrm{W}$ for phases $1-4$ and 8 and TES has a slightly larger signal for some phases (e.g., phase 7 over Indian Ocean). A detailed ozone budget is given in Sect. 4.4.

Figure 7 (left panel) shows the ozone anomalies from the model simulation without applying the TES operator. The 
difference in magnitude of the ozone anomalies associated with the MJO between Figs. 6 and 7 shows that the TES operator flattens the ozone anomalies and decreases the magnitude by $50 \%$. The TES operator also changes the relative magnitude of the signal between phases. When the TES operator is applied, only phases 1 and 8 are particularly enhanced, while the raw model output suggests the ozone signal is not considerably weaker during the other phases. Thus, while the magnitude of the ozone anomaly with the TES operator appears to weaken considerably between phases 1 and 2, this is not apparent in the raw model simulations. Instead the positive ozone anomaly located near $60^{\circ} \mathrm{E}$ during phase 1 moves eastward with little diminishment in amplitude until phase 4 in the raw model simulations, while to its west, it is replaced by a pronounced negative anomaly with eastward propagation. In addition, the relationship between the downward vertical velocity and the positive ozone anomaly is much clearer and more consistent without the TES operator.

An MJO signal is also apparent in the lower troposphere when the TES operator is not applied, particularly in the western part of the domain. An eastward-propagating negative anomaly is apparent from phase 1 to 5 below $500 \mathrm{hPa}$ west of the dateline, with an eastward-propagating positive anomaly from phase 3 to 8 . East of the dateline, lower tropospheric anomalies are apparent but less distinct with a less distinct propagation. The upper and lower tropospheric MJO anomalies are often out of phase in the western part of the domain with an apparent east-to-west tilt. This can be traced to vertical differences in the sign of the vertical velocity fields and their east-to-west tilt (e.g., Sperber, 2003).

\subsection{Impact of lightning on the MJO-related tropospheric ozone anomalies}

The comparison of MJO-related ozone anomalies between the control run and the run with lightning turned off (without applying the TES operator) is given in Fig. 7. With the lightning turned on, the model-simulated ozone anomalies on the intra-seasonal timescale are much larger, about 5 times bigger as those without lightning. However, a similar anomaly pattern is still present. The spatial correlation coefficient between the run with and without lightning is on average 0.89 for the eight phases (significant at the $95 \%$ confidence level). This suggests that while lightning and the associated chemistry act to enhance the MJO-related tropospheric ozone anomalies, they do not fundamentally change their vertical and horizontal structure.

\subsection{MJO-related tropospheric ozone tendencies}

To explain the equatorial tropospheric ozone's response to the MJO, we calculate the five terms in Eq. (1) using model results and we show the three major terms (advection, deep convection and net chemistry) in Fig. 8 (only phase 1, 3, 5, 7 are shown for simplicity). The total ozone tendency term explains the change between phases in Fig. 7. For example, the negative ozone tendency near $60^{\circ} \mathrm{E}$ in phase 1 is consistent with the change of the positive ozone anomalies in phase 1 to the negative ozone anomalies in phase 2 (Fig. 7) there. In phases 3 and 7, the ozone tendencies $\left(0-120^{\circ} \mathrm{E}\right.$ and $120^{\circ} \mathrm{E}-60^{\circ} \mathrm{W}$ ) are in phase with the ozone anomalies, explaining the enhanced ozone anomalies in phase 4 and 8 and the pause of the eastward movement (Fig. 7). The similarity of the patterns of the total ozone tendency and that due to advection suggests that advection is the driving force for the ozone change during the MJO (the spatial correlation coefficients are $0.74,0.65,0.72,0.70$ for phase $1,3,5,7$, respectively, significant at the $95 \%$ confidence level). However, in a few specific locations other processes dominate (e.g., chemistry near $90^{\circ} \mathrm{W}$ for phase 1 and phase 5). Overall, the ozone generally decreases where there is upward motion (negative omega), and increases where there is downward motion (positive omega). However, it is clear that omega alone does not give the complete story. The advective ozone flux also depends on vertical ozone gradients (see Fig. 1) and horizontal advection. As stated previously, it is very difficult to separate the horizontal and vertical transport from the advection in the current model simulation.

The net chemistry effect is significantly smaller in magnitude than advection, despite the importance of lightning in determining the magnitude of the MJO-related tropospheric ozone anomalies (Sect. 4.3, Fig. 7). The explanation of this apparent paradox lies in the fact that lightning increases both the vertical and horizontal gradients of ozone (compare Fig. 3a with 1a). The increased vertical and horizontal ozone gradients enhance ozone advection, the largest term driving the MJO-related tropospheric ozone anomalies (Fig. 8). The deep convective transport is small compared with the advective transport. Shallow convection and vertical diffusion are negligible compared with the previous three terms, consistent with the Zhang and $\mathrm{Mu}$ (2005) observation that shallow convection in the composite MJO cycle is very weak (their Fig. 12b).

\subsection{MJO chemical variability}

Figure 9 shows the percentage variability of ozone and $\mathrm{OH}$ related to the MJO. Variability of $\mathrm{OH}$ and $\mathrm{O}_{3}$ due to the $\mathrm{MJO}$ generally ranges from 25 to $40 \%$ of the total variability (from daily to interannual) across much of the tropics and throughout the depth of the troposphere. The maximum ozone variability caused by the MJO reaches $47 \%$ of the total variability near 60 and $130^{\circ} \mathrm{E}$ at $200 \mathrm{hPa}$ and $80^{\circ} \mathrm{E}$ at $500 \mathrm{hPa}$. The relative variability of $\mathrm{OH}$ generally resembles that of ozone reaching a maximum of $40 \%$, but is generally somewhat weaker. Generally, the three regions where the highest intra-seasonal variability of ozone and $\mathrm{OH}$ occurs $\left(60-90^{\circ} \mathrm{E}\right.$, $150^{\circ} \mathrm{E}$, and $120-90^{\circ} \mathrm{W}$ ) appear to be loosely related to the intra-seasonal variability of lightning (Fig. 9c). 

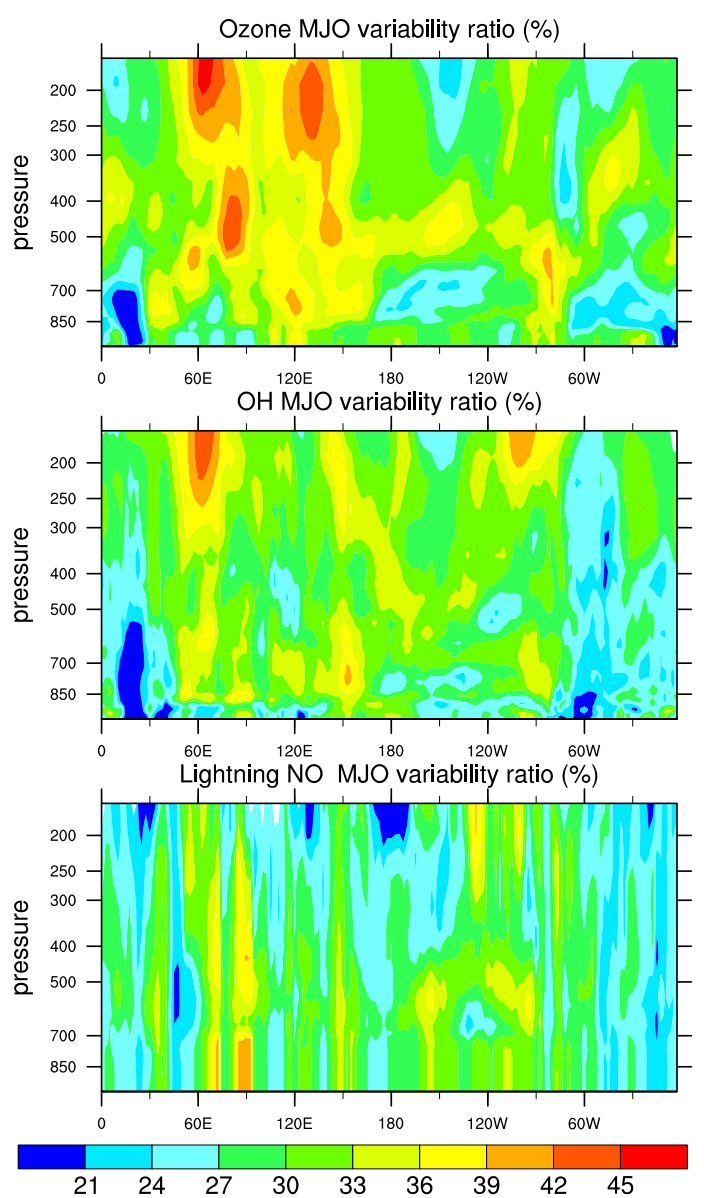

Figure 9. MJO variability ratio (given in percentage) for ozone, $\mathrm{OH}$ and lightning NO.

\section{Conclusions}

The role of the MJO in total column ozone has been discussed before, but its connection with the tropospheric column ozone in the equatorial region in both model and observation has yet to be investigated in detail. This is the first study that documents the equatorial MJO-related tropospheric ozone oscillation in both a chemical transport model and satellite observations. We find that the model, when driven by analyzed meteorology, can adequately simulate the MJO-related tropospheric ozone anomalies as measured from satellites. The MJO contributes substantially to the variability of both $\mathrm{OH}$ and ozone across the tropics, about 25$40 \%$ but up to $50 \%$ in selected regions.

CAM-chem is able to qualitatively reproduce the equatorial ozone climatology during boreal winter; the simulated ozone distribution with the TES averaging kernel applied and the satellite ozone distribution are highly correlated, with the spatial correlation coefficient of 0.84 from $200 \mathrm{hPa}$ to surface. However, there are some deficiencies of the CAM-chem model simulation. For example, CAM-chem generally has a positive ozone bias of $(\sim 10 \mathrm{ppb})$ compared with TES, with the largest bias located near $120-60^{\circ} \mathrm{W}$. In the middle troposphere over the western Pacific (near $150^{\circ} \mathrm{E}$ ), the CAMchem-simulated ozone is less than the measured ( $\sim 10 \mathrm{ppb})$. In the boundary layer, the CAM-chem is positively biased compared with TES. Lightning plays an important role in determining the climatological mean ozone. The difference between the control run model simulation and the model simulation with no lightning reaches up to $30 \mathrm{ppb}$ in the upper troposphere near $60^{\circ} \mathrm{W}$ and $10^{\circ} \mathrm{E}$ (where the lightning $\mathrm{NO}_{\mathrm{x}}$ source is maximum). Lightning also increases the vertical and horizontal ozone gradients compared to a simulation with no lightning.

In the boreal winter (November through April) climatologically high ozone concentrations are evident throughout most of the depth of the troposphere in both simulation and measurements from 30 to $60^{\circ} \mathrm{E}$; near $150^{\circ} \mathrm{E}$, low ozone concentrations are evident in both. The low ozone concentrations near $150^{\circ} \mathrm{E}$ occur throughout the depth of the troposphere. They occur in association with a precipitation maximum and have been attributed to convection transporting low ozone concentrations from the boundary layer to the upper troposphere (Lelieveld et al., 2001), although in the simulation large-scale vertical advection is also important. The TES operator does not dramatically change the simulated climatological ozone distribution, although the result of applying the TES operator is to increase the boundary layer ozone and reduce the upper tropospheric ozone (near $180^{\circ} \mathrm{E}$ ).

The behavior of TTC ozone on the intra-seasonal timescale is different from that of the total column ozone, especially in the equatorial region. The TTC ozone anomalies related to $\mathrm{MJO}(\sim 2 \mathrm{DU})$ propagate eastward in the tropical region, with the signal maximizing in the Indian Ocean and the western Pacific in association with the largest vertical velocities. Significantly, the magnitude of MJO-related TTC ozone anomalies in the equatorial region is comparable to that in the subtropics. The TTC ozone anomalies move eastward with the eastward propagation of the large-scale MJO convective and dynamical signals. The patterns of modelsimulated and satellite-measured TTC ozone anomalies and precipitation anomalies for the eight phases of the MJO are in overall agreement with the TES measurements both in the tropics and the subtropics (Figs. 5, 6), although the magnitude and the spatial scale of the precipitation anomalies in CAM-chem are smaller than that observed using TRMM.

While the vertical resolution of TES in the troposphere is somewhat limited, when the TES operator is applied to the simulated ozone profiles, the modeled and measured ozone anomalies generally agree in pattern and amplitude with altitude, with the average spatial correlation coefficient as 0.63 for the eight phases. The ozone signal in the eastern portion of the equatorial domain propagates very little but is generally out of phase with the signal in the western portion of the equatorial domain. However, the MJO in the CAMchem looks somewhat different without the averaging kernel 
applied. The TES operator flattens the ozone anomalies and decreases the magnitude to $\sim 50 \%$, and also changes the relative magnitude of the signal between phases. When the TES operator is applied, only phases 1 and 8 are particularly enhanced, while the raw model output suggests the ozone signal is not considerably weaker during the other phases.

Large-scale advection explains most of the simulated ozone changes associated with the MJO. While many of the simulated changes appear related to the vertical velocity perturbations, the correlation between the advective ozone tendency and omega is generally small. Lightning $\mathrm{NO}_{\mathrm{x}}$ emissions enhance the amplitude of the MJO ozone anomalies by about a factor of 5 over a simulation without lightning $\mathrm{NO}_{\mathrm{x}}$ emissions, despite the fact that changes in the chemical tendency associated with the MJO are small. Lightning increases the horizontal and vertical ozone gradients, thus increasing the advective ozone anomalies.

The tropics represent an important, but often overlooked, region in the atmospheric processing of chemical constituents. Most chemistry transport models are only given a cursory evaluation in the tropics. The equatorial MJO in ozone represents up to $47 \%$ of the variability of equatorial ozone. We have shown that the signal is mostly due to largescale atmospheric circulations, allowing it to be represented in coarse scale models; we have also shown a model simulation driven by analyzed winds is able to adequately represent the equatorial MJO. However, the ability of climate GCMs to represent the equatorial MJO in ozone is not well known.

Acknowledgements. This work was supported by the National Science Foundation through grant ATM-57003 to Cornell University and grant ATM-0840755 to University of California, Los Angeles. Part of this research was performed at the Jet Propulsion Laboratory (JPL), California Institute of Technology (Caltech), under a contract with National Aeronautics and Space Administration (NASA). The authors would like to thank Helen Worden for help with the TES satellite data.

Edited by: B. N. Duncan

\section{References}

Andreae, M. O. and Merlet, P.: Emission of trace gases and aerosols from biomass burning, Global Biogeochem. Cy., 15, 955-966, 2001.

Baughcum, S., Henderson, S., and Sutkus, D.: Scheduled civil aircraft emission inventories projected for 2015: Database development and analysis, NASA Contract. Rep NASA CR, under NASA contract, NASA Goddard Space Flight Cent., Greenbelt, 1998.

Baughcum, S. L., Tritz, T. G., Henderson, S. C., and Pickett, D. C.: Scheduled civil aircraft emission inventories for 1992: Database development and analysis, National Aeronautics and Space Administration, Langley Research Center, 1996.
Beer, R.: TES on the Aura mission: Scientific objectives, measurements, and analysis overview, IEEE T. Geosci. Remote, 44, 1102-1105, 2006.

Beer, R., Glavich, T. A., and Rider, D. M.: Tropospheric emission spectrometer for the Earth Observing System's Aura satellite, Appl. Optics, 40, 2356-2367, 2001.

Bowman, K. W., Rodgers, C. D., Kulawik, S. S., Worden, J., Sarkissian, E., Osterman, G., Steck, T., Lou, M., Eldering, A., Shephard, M., Worden, H., Lampel, M., Clough, S., Brown, P., Rinsland, C., Gunson, M., and Beer, R.: Tropospheric emission spectrometer: Retrieval method and error analysis, IEEE T. Geosci. Remote, 44, 1297-1307, 2006.

Bowman, K. W., Jones, D. B. A., Logan, J. A., Worden, H., Boersma, F., Chang, R., Kulawik, S., Osterman, G., Hamer, P., and Worden, J.: The zonal structure of tropical $\mathrm{O}_{3}$ and $\mathrm{CO}$ as observed by the Tropospheric Emission Spectrometer in November 2004 - Part 2: Impact of surface emissions on $\mathrm{O}_{3}$ and its precursors, Atmos. Chem. Phys., 9, 3563-3582, doi:10.5194/acp-93563-2009, 2009.

Cooper, M. J., Martin, R. V., Livesey, N. J., Degenstein, D. A., and Walker, K. A.: Analysis of satellite remote sensing observations of low ozone events in the tropical upper troposphere and links with convection, Geophys. Res. Lett., 40, 3761-3765, 2013.

Doherty, R. M., Stevenson, D. S., Collins, W. J., and Sanderson, M. G.: Influence of convective transport on tropospheric ozone and its precursors in a chemistry-climate model, Atmos. Chem. Phys., 5, 3205-3218, doi:10.5194/acp-5-3205-2005, 2005.

Eldering, A., Kulawik, S. S., Worden, J., Bowman, K., and Osterman, G.: Implementation of cloud retrievals for TES atmospheric retrievals: 2. Characterization of cloud top pressure and effective optical depth retrievals, J. Geophys. Res.-Atmos., 113, 19842012, D16S37, doi:10.1029/2007JD008858, 2008.

Emmons, L. K., Walters, S., Hess, P. G., Lamarque, J.-F., Pfister, G. G., Fillmore, D., Granier, C., Guenther, A., Kinnison, D., Laepple, T., Orlando, J., Tie, X., Tyndall, G., Wiedinmyer, C., Baughcum, S. L., and Kloster, S.: Description and evaluation of the Model for Ozone and Related chemical Tracers, version 4 (MOZART-4), Geosci. Model Dev., 3, 43-67, doi:10.5194/gmd3-43-2010, 2010.

Folkins, I. and Martin, R. V.: The vertical structure of tropical convection and its impact on the budgets of water vapor and ozone., J. Atmos. Sci., 62, 1560-1573, 2005.

Folkins, I., Braun, C., Thompson, A. M., and Witte, J.: Tropical ozone as an indicator of deep convection, J. Geophys. Res.Atmos., 107, ACH 13-1-ACH 13-10, 2002.

Garcia, R., Marsh, D., Kinnison, D., Boville, B., and Sassi, F.: Simulation of secular trends in the middle atmosphere, 1950-2003, J. Geophys. Res.-Atmos., 112, D09301, doi:10.1029/2006JD007485, 2007.

Granier, C., Lamarque, J., Mieville, A., Muller, J., Olivier, J., Orlando, J., Peters, J., Petron, G., Tyndall, G., and Wallens, S.: POET, a database of surface emissions of ozone precursors, available at: http://www.aero.jussieu.fr/projet/ACCENT/POET. php 2005.

Guenther, A., Karl, T., Harley, P., Wiedinmyer, C., Palmer, P. I., and Geron, C.: Estimates of global terrestrial isoprene emissions using MEGAN (Model of Emissions of Gases and Aerosols from Nature), Atmos. Chem. Phys., 6, 3181-3210, doi:10.5194/acp-63181-2006, 2006. 
Hack, J. J., Caron, J. M., Yeager, S. G., Oleson, K. W., Holland, M. M., Truesdale, J. E., and Rasch, P. J.: Simulation of the global hydrological cycle in the CCSM Community Atmosphere Model version 3 (CAM3): Mean features., J. Clim., 19, 2199-2221, doi:10.1175/JCLI3755.1, 2006.

Hendon, H. H. and Salby, M. L.: The life cycle of the Madden-Julian oscillation, J. Atmos. Sci., 51, 2225-2237, 1994.

Holtslag, A. and Boville, B.: Local versus nonlocal boundary-layer diffusion in a global climate model, J. Clim., 6, 1825-1842, 1993.

Houghton, J. T., Ding, Y., Griggs, D. J., Noguer, M., van der LINDEN, P. J., Dai, X., Maskell, K., and Johnson, C.: Climate change 2001: the scientific basis, Cambridge university press Cambridge, 881, 2001.

Huffman, G. J., Adler, R. F., Bolvin, D. T., Gu, G., Nelkin, E. J., Bowman, K. P., Hong, Y., Stocker, E. F., and Wolff, D. B.: The TRMM Multisatellite Precipitation Analysis (TMPA): Quasiglobal, multiyear, combined-sensor precipitation estimates at fine scales, J. Hydrometeorol., 8, 38-55, doi:10.1175/JHM560.1, 2007.

Jee-Hoon, J., Baek-Min, K., Chang-Hoi, H., and Yeon-Hee, N.: Systematic Variation in Wintertime Precipitation in East Asia by MJO-Induced Extratropical Vertical Motion., J. Clim., 21, 788801,2008

Jourdain, L., Worden, H., Worden, J., Bowman, K., Li, Q., Eldering, A., Kulawik, S., Osterman, G., Boersma, K., Fisher, B., Rinsland, C. P., Beer, R., and Gunson, M.: Tropospheric vertical distribution of tropical Atlantic ozone observed by TES during the northern African biomass burning season, Geophys. Res. Lett., 34, L04810, doi:10.1029/2006GL028284, 2007.

Kulawik, S. S., Worden, H., Osterman, G., Luo, M., Beer, R., Kinnison, D. E., Bowman, K. W., Worden, J., Eldering, A., Lampel, M., Steck, T., and Rodgers, C. D.: TES atmospheric profile retrieval characterization: An orbit of simulated observations, IEEE T. Geosci. Remote, 44, 1324-1333, 2006.

Labrador, L. J., von Kuhlmann, R., and Lawrence, M. G.: The effects of lightning-produced $\mathrm{NO}_{\mathrm{x}}$ and its vertical distribution on atmospheric chemistry: sensitivity simulations with MATCHMPIC, Atmos. Chem. Phys., 5, 1815-1834, doi:10.5194/acp-51815-2005, 2005.

Lacis, A. A., Wuebbles, D. J., and Logan, J. A.: Radiative forcing of climate by changes in the vertical distribution of ozone, J. Geophys. Res.-Atmos., 95, 9971-9981, 1990.

Lamarque, J.-F., Emmons, L. K., Hess, P. G., Kinnison, D. E., Tilmes, S., Vitt, F., Heald, C. L., Holland, E. A., Lauritzen, P. H., Neu, J., Orlando, J. J., Rasch, P. J., and Tyndall, G. K.: CAM-chem: description and evaluation of interactive atmospheric chemistry in the Community Earth System Model, Geosci. Model Dev., 5, 369-411, doi:10.5194/gmd-5-369-2012, 2012.

Lau, W. K. and Waliser, D. E.: El Nino southern oscillation connection, in: Intraseasonal Variability in the Atmosphere-Ocean Climate System, Springer, 297-334, 2012.

Lawrence, M., Chameides, W., Kasibhatla, P., Levy II, H., and Moxim, W.: Lightning and atmospheric chemistry: The rate of atmospheric NO production, Handbook of atmospheric electrodynamics, 1, 189-202, 1995.

Lawrence, M. G., von Kuhlmann, R., Salzmann, M., and Rasch, P. J.: The balance of effects of deep convective mix- ing on tropospheric ozone, Geophys. Res. Lett., 30, 1940, doi:10.1029/2003GL017644, 2003.

Lelieveld, J. and Crutzen, P. J.: Role of deep cloud convection in the ozone budget of the troposphere, Science, 264, 1759-1761, 1994.

Lelieveld, J. and Dentener, F. J.: What controls tropospheric ozone?, J. Geophys. Res.-Atmos., 105, 3531-3551, doi:10.1029/1999JD901011, 2000.

Lelieveld, J. O., Crutzen, P., Ramanathan, V., Andreae, M., Brenninkmeijer, C., Campos, T., Cass, G., Dickerson, R., Fischer, H., De Gouw, J., Hansel, A., Jefferson, A., Kley, D., de Laat, A. T. J., Lal, S., Lawrence, M. G., Lobert, J. M., Mayol-Bracero, O. L., Mitra, A. P., Novakov, T., Oltmans, S. J., Prather, K. A., Reiner, T., Rodhe, H., Scheeren, H. A., Sikka, D., and Williams, J.: The Indian Ocean experiment: widespread air pollution from South and Southeast Asia, Science, 291, 1031-1036, 2001.

Li, K.-F., Tian, B., Waliser, D. E., Schwartz, M. J., Neu, J. L., Worden, J. R., and Yung, Y. L.: Vertical structure of MJO-related subtropical ozone variations from MLS, TES, and SHADOZ data, Atmos. Chem. Phys., 12, 425-436, doi:10.5194/acp-12425-2012, 2012.

Li, K.-F., Tian, B., Tung, K.-K., Kuai, L., Worden, J. R., Yung, Y. L., and Slawski, B. L.: A link between tropical intraseasonal variability and Arctic stratospheric ozone, J. Geophys. Res.-Atmos., 118, 4280-4289, 2013.

Logan, J. A., Prather, M. J., Wofsy, S. C., and McElroy, M. B.: Tropospheric chemistry: A global perspective, J. Geophys. Res.Oceans, 86, 7210-7254, doi:10.1029/JC086iC08p07210, 1981.

Madden, R. A. and Julian, P. R.: Detection of a 40-50 day oscillation in the zonal wind in the tropical Pacific, J. Atmos. Sci., 28, 702-708, 1971.

Madden, R. A. and Julian, P. R.: Description of global-scale circulation cells in the tropics with a 40-50 day period, J. Atmos. Sci., 29, 1109-1123, 1972.

Martin, R. V., Jacob, D. J., Logan, J. A., Bey, I., Yantosca, R. M., Staudt, A. C., Li, Q., Fiore, A. M., Duncan, B. N., Liu, H., Ginoux, P., and Thouret, V.: Interpretation of TOMS observations of tropical tropospheric ozone with a global model and in situ observations, J. Geophys. Res.-Atmos., 107, 4351, doi:10.1029/2001JD001480, 2002.

Mortlock, A. and Van Alstyne, R.: Military, Charter, Unreported Domestic Traffic and General Aviation 1976, 1984, 1992, and 2015 Emission Scenarios, National Aeronautics and Space Administration, Langley Research Center, 1998.

Nassar, R., Logan, J. A., Worden, H. M., Megretskaia, I. A., Bowman, K. W., Osterman, G. B., Thompson, A. M., Tarasick, D. W., Austin, S., Claude, H., Dubey, M. K., Hocking, W. K., Johnson, B. J., Joseph, E., Merrill, J., Morris, G. A., Newchurch, M., Oltmans, S. J., Posny, F., Schmidlin, F. J., Vömel, H., Whiteman. D. N., and Witte, J. C.: Validation of Tropospheric Emission Spectrometer (TES) nadir ozone profiles using ozonesonde measurements, J. Geophys. Res.- Atmos., 113, D15S17, doi:10.1029/2007JD008819, 2008.

Osterman, G., Kulawik, S., Worden, H., Richards, N., Fisher, B., Eldering, A., Shephard, M., Froidevaux, L., Labow, G., Luo, M., Herman, R. L., Bowman, K. W., and Thompson, A. M.: Validation of Tropospheric Emission Spectrometer (TES) measurements of the total, stratospheric, and tropospheric column 
abundance of ozone, J. Geophy. Res.-Atmos., 113, D15S16, doi:10.1029/2007JD008801, 2008.

Pickering, K. E., Wang, Y., Tao, W.-K., Price, C., and Müller, J.F.: Vertical distributions of lightning NOx for use in regional and global chemical transport models, J. Geophys. Res.-Atmos., 103, 31203-31216, 1998.

Price, C. and Rind, D.: A simple lightning parameterization for calculating global lightning distributions, J. Geophys. Res.-Atmos., 97, 9919-9933, 1992.

Price, C., Penner, J., and Prather, M.: $\mathrm{NO}_{\mathrm{x}}$ from lightning: 1. Global distribution based on lightning physics, J. Geophys. Res.- Atmos., 102, 5929-5941, 1997.

Randel, W. J. and Jensen, E. J.: Physical processes in the tropical tropopause layer and their roles in a changing climate, Nature Geoscience, 6, 169-176, 2013.

Richards, N. A., Osterman, G. B., Browell, E. V., Hair, J. W., Avery, M., and Li, Q.: Validation of Tropospheric Emission Spectrometer ozone profiles with aircraft observations during the Intercontinental Chemical Transport Experiment-B, J. Geophys. Res.-Atmos., 113, D16S29, doi:10.1029/2007JD008815,, 2008.

Rodgers, C. D.: Inverse methods for atmospheric sounding: Theory and practice, , World scientific Singapore, 2, 2000.

Sauvage, B., Martin, R. V., Van Donkelaar, A., and Ziemke, J.: Quantification of the factors controlling tropical tropospheric ozone and the South Atlantic maximum, J. Geophys.Res.Atmos., 112, D11309, doi:10.1029/2006JD008008, 2007.

Sperber, K. R.: Propagation and the vertical structure of the Madden-Julian Oscillation, Mon. Weather Rev., 131, 3018-3037, 2003.

Sutkus, D. J., Baughcum, S. L., and DuBois, D. P.: Scheduled civil aircraft emission inventories for 1999: database development and analysis, National Aeronatics and Space Administration (NASA) Glenn Research Center, Contract NAS1-20341, NASA/CR-2001-211216, 2001.

Thompson, A. M., Witte, J. C., Oltmans, S. J., Schmidlin, F. J., Logan, J. A., Fujiwara, M., Kirchhoff, V. W., Posny, F., Coetzee, G. J., Hoegger, B., Kawakami, S., Ogawa, T., Fortuin, J. P. F., and Kelder, H. M.: Southern Hemisphere Additional Ozonesondes (SHADOZ) 1998-2000 tropical ozone climatology 2, Tropospheric variability and the zonal wave-one, J. Geophys. Res.Atmos., 108, 8241, doi:10.1029/2002JD002241, 2003.

Tian, B. and Waliser, D. E.: Chemical and biological impacts, Intraseasonal Variability in the Atmosphere, Ocean Climate System, 2, 569-585, 2011.

Tian, B., Yung, Y., Waliser, D., Tyranowski, T., Kuai, L., Fetzer, E., and Irion, F.: Intraseasonal variations of the tropical total ozone and their connection to the Madden-Julian Oscillation, Geophys. Res. Lett., 34, L08704, doi:10.1029/2007GL029451, 2007.

Tian, B., Waliser, D. E., Fetzer, E. J., and Yung, Y. L.: Vertical Moist Thermodynamic Structure of the Madden-Julian Oscillation in Atmospheric Infrared Sounder Retrievals: An Update and a Comparison to ECMWF Interim Re-Analysis., Mon. Weather Rev., 138, 4576-4582, doi:10.1175/2010MWR3486.1, 2010.

Tian, B., Waliser, D. E., Kahn, R. A., and Wong, S.: Modulation of Atlantic aerosols by the Madden-Julian Oscillation, J. Geophys. Res.-Atmos., 116, D15108, doi:10.1029/2010JD015201, 2011. van der Werf, G. R., Randerson, J. T., Giglio, L., Collatz, G. J., Kasibhatla, P. S., and Arellano Jr., A. F.: Interannual variability in global biomass burning emissions from 1997 to 2004, Atmos. Chem. Phys., 6, 3423-3441, doi:10.5194/acp-6-3423-2006, 2006.

Virts, K. S., Thornton, J. A., Wallace, J. M., Hutchins, M. L., Holzworth, R. H., and Jacobson, A. R.: Daily and intraseasonal relationships between lightning and $\mathrm{NO}_{2}$ over the Maritime Continent, Geophys. Res. Lett., 38, L19803, doi:10.1029/2011GL048578, 2011.

Virts, K. S., Wallace, J. M., Hutchins, M. L., and Holzworth, R. H.: Diurnal Lightning Variability over the Maritime Continent: Impact of Low-Level Winds, Cloudiness, and the MJO, J. Atmos. Sci., 70, 3128-3146, doi:10.1175/JAS-D-13-021.1, 2013.

Wheeler, M. C. and Hendon, H. H.: An all-season real-time multivariate MJO index: Development of an index for monitoring and prediction, Mon. Weather Rev., 132, 1917-1932, doi:10.1175/1520-0493(2004)132<1917:AARMMI>2.0.CO;2, 2004.

Worden, H., Logan, J., Worden, J., Beer, R., Bowman, K., Clough, S., Eldering, A., Fisher, B., Gunson, M., Herman, R., et al.: Comparisons of Tropospheric Emission Spectrometer (TES) ozone profiles to ozonesondes: Methods and initial results, J. Geophys. Res.-Atmos., 112, D09308,doi:10.1029/2004JD004522, 2007.

Worden, H. M., Bowman, K. W., Worden, J. R., Eldering, A., and Beer, R.: Satellite measurements of the clear-sky greenhouse effect from tropospheric ozone, Nat. Geosci., 1, 305-308, 2008.

Worden, J., Kulawik, S. S., Shephard, M. W., Clough, S. A., Worden, H., Bowman, K., and Goldman, A.: Predicted errors of tropospheric emission spectrometer nadir retrievals from spectral window selection, J. Geophys. Res.-Atmos., 109, D09308, doi:10.1029/2004JD004522, 2004.

Zhang, C.: Madden-julian oscillation, Rev. Geophys., 43, RG2003, doi:10.1029/2004RG000158, 2005.

Zhang, G. J. and McFarlane, N. A.: Sensitivity of climate simulations to the parameterization of cumulus convection in the Canadian Climate Centre general circulation model, Atmos. Ocean, 33, 407-446, 1995.

Zhang, G. J. and Mu, M.: Simulation of the Madden-Julian Oscillation in the NCAR CCM3 Using a Revised Zhang-McFarlane Convection Parameterization Scheme, J. Clim., 18, 4046-4064, doi:10.1175/JCLI3508.1, 2005.

Ziemke, J. and Chandra, S.: A Madden-Julian Oscillation in tropospheric ozone, Geophys. Res. Lett., 30, 2182, doi:10.1029/2003GL018523, 2003.

Ziemke, J., Chandra, S., Schoeberl, M., Froidevaux, L., Read, W., Levelt, P., and Bhartia, P.: Intra-seasonal variability in tropospheric ozone and water vapor in the tropics, Geophys. Res. Lett., 34, L17804, doi:10.1029/2007GL030965, 2007.

Ziemke, J. R., Joiner, J., Chandra, S., Bhartia, P. K., Vasilkov, A., Haffner, D. P., Yang, K., Schoeberl, M. R., Froidevaux, L., and Levelt, P. F.: Ozone mixing ratios inside tropical deep convective clouds from OMI satellite measurements, Atmos. Chem. Phys., 9, 573-583, doi:10.5194/acp-9-573-2009, 2009. 